<総 説 $>$

(受理 : 平成 23 年 8 月 15 日)

\title{
光学フィルム用強粘着表面保護フィルム Protective Film of High Adhesion Type for Optical Sheet
}

豊嶋 克典*・家田 泰享 ${ }^{* *}$ ・野世渓 元 ${ }^{*}$ ・多田 博士 ${ }^{* *}$ Katsunori TOYOSHIMA, Yasuyuki IEDA, Hajime NOSETANI and Hiroshi TADA

\section{1. 緒 言}

液晶ディスプレイ（以下 LCD）は，1970 年代初頭に表 示デバイスとして初めて製品化されて以来，電卓，時計を 出発点として, 携帯電話・デジタルカメラ・カーナビゲー ション用のような中小型用途から，ノートパソコンやディ スクトップパソコン用のモニター, さらにはTV市場へ 大きく用途が拡大している。図 1 のパネル断面図が示すよ うに, LCD は非常に多くのフィルムの積層体から構成さ れている。LCDの画質向上に，光学フィルムは欠かせな いものとなっており, 輝度を向上させる目的で, 輝度上昇 フィルムや拡散フィルム等の光学フィルムが使用されてい る1)。これらのフィルムの製造には, 工程中や出荷時にお ける污れ, 傷防止のための表面保護や, 裁断工程における 保持搬送などに，表面保護フィルムを使用する場合が多い。 図 2 に示すように, 輝度上昇フィルムの表面には数十 $\mu \mathrm{m}$ の凹凸があり，また拡散フィルムの表面には数 $\mu \mathrm{m}$ の凹凸 がある。通常の表面が平滑な被着体と比較すると接触面積 が非常に小さく，表面保護フィルムを貼り付けにくい被着 体の代表例である ${ }^{2)}$ 。したがって光学フィルムには, 強粘 着タイプの表面保護フィルムが使用される゙3)。

本稿においては, 表面保護フィルムの性能および, 粘着 層の樹脂設計について報告する。

* 積水化学工業 (綝) 高機能プラスチックスカンパニー 武蔵工 場 工業テープ製造部

埼玉県蓮田市大字黒浜 3535 † 349-0198

SEKISUI CHEMICAL CO., LTD

3535 Kurohama Hashuda-shi Saitama 349-0198 Japan

** 積水化学工業 (保) 高機能プラスチックスカンパニー 開発研 究所

大阪府三島郡島本町百山 $2-1$ \% 618-0021

SEKISUI CHEMICAL CO., LTD

2-1 Hyakuyama Shimamoto-cho Mishima-gun Osaka 618 -8589 Japan

(平成 23 年日本接着学会技術賞受賞)

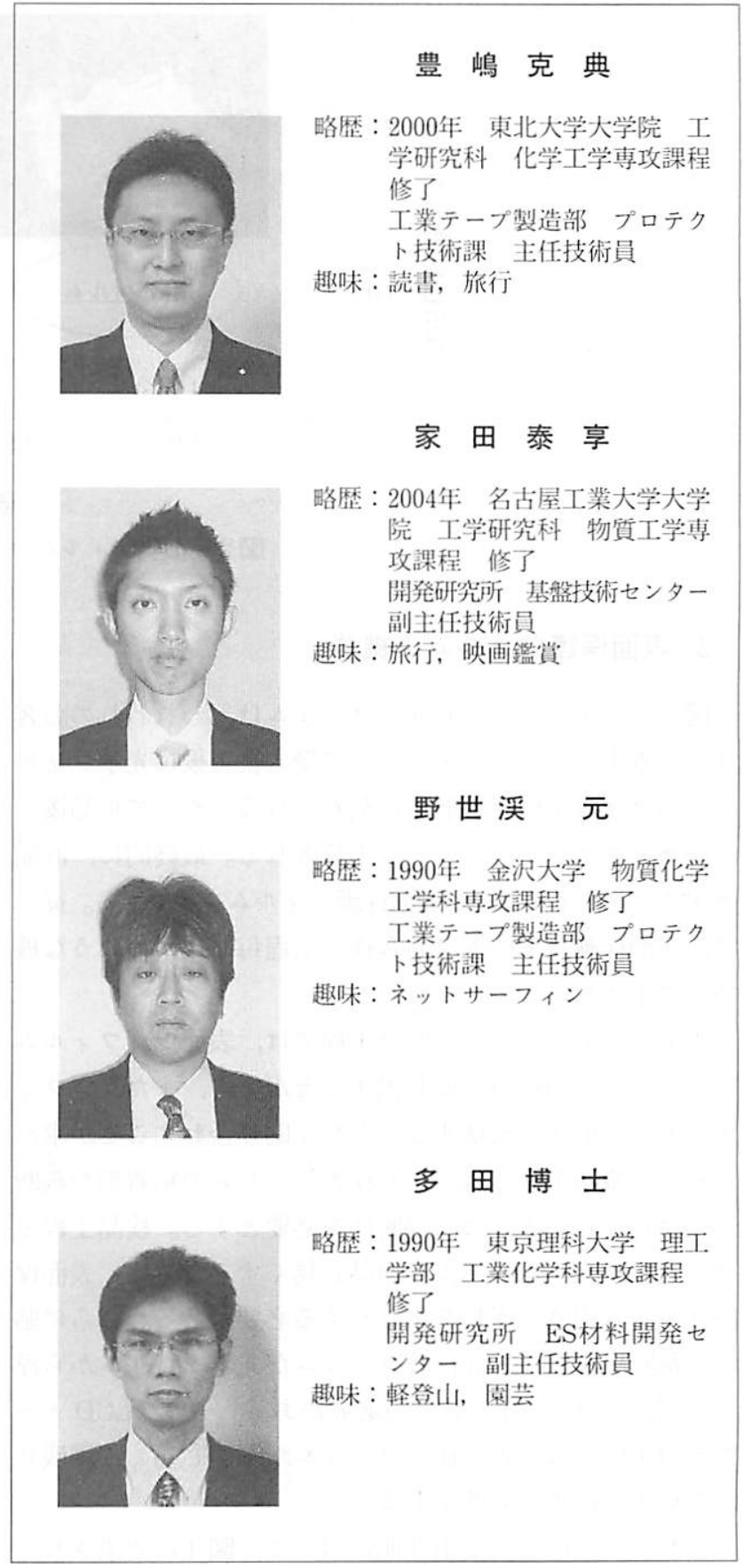




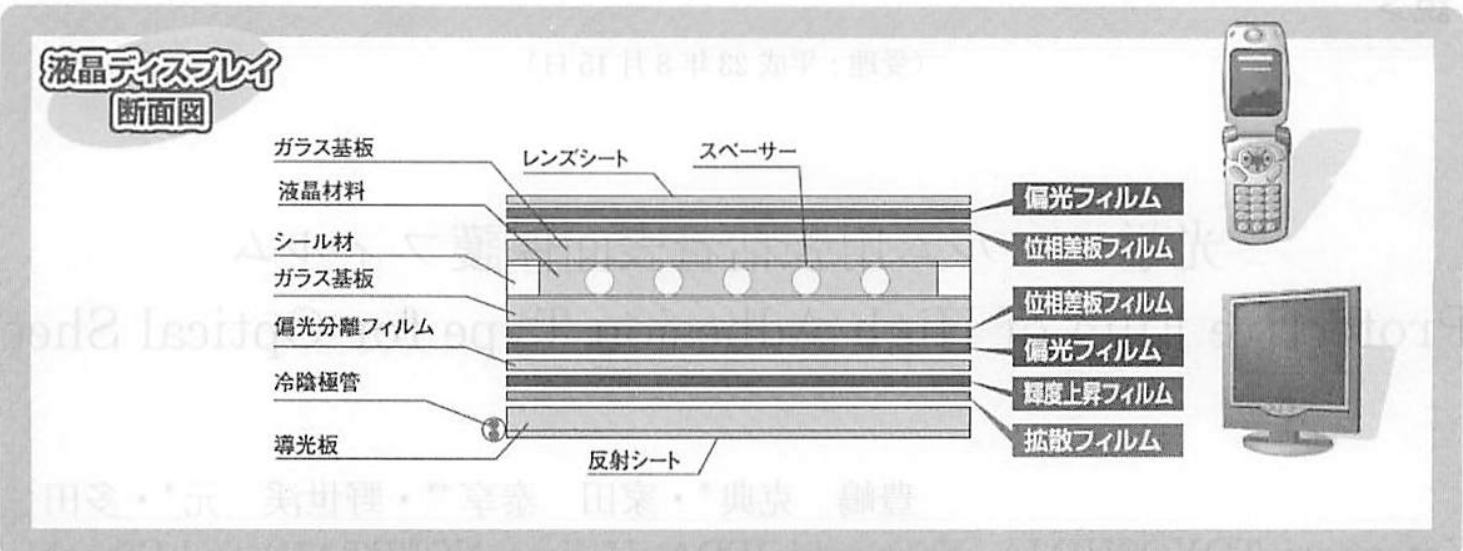

図 1 LCD パネルの断面図

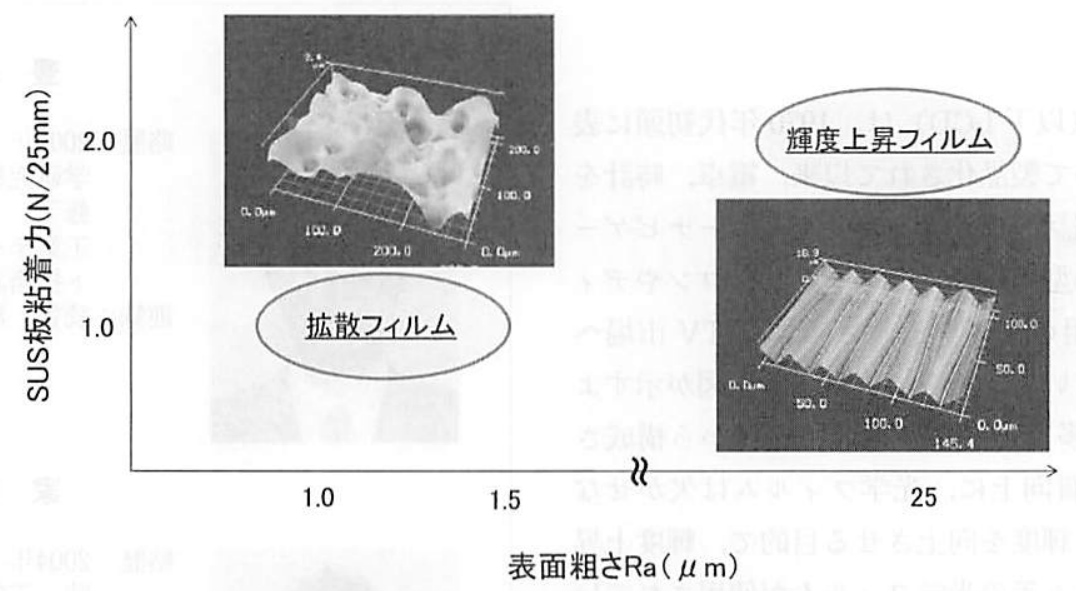

図 2 光学フィルムの表面粗さと SUS 板粘着力

\section{2. 表面保護フィルムの機能}

図 3 に示すように表面保護フィルムは，われわれのお客 様である光学フィルムメーカーで受入検査後に光学フィル ムに貼合されて任意の形状に裁断される。そして検品後, 液晶ディスプレイメーカーに出荷される。最終的に, 液晶 ディスプレイメーカーが表面保護フィルムを除去する。従っ て，表面保護フィルムはお客様の工程毎に以下のような機 能が要求される。

光学シートメーカーの貼合工程では, 表面保護フィルム をロールから弱い力で繰り出すことができ, また光学フィ ルム表面の形状を破壊することなく貼り合わすことが求め られる。裁断工程では，表面保護フィルムの粘着剤が裁断 刃に付着しないように易切断性を必要とする。検品工程で は, 光学フィルムの不良を検品し易くするために, 表面保 護フィルム内外の異物を少なくする必要がある。さらに貼 合, 裁断工程後に表面保護フィルムが光学フィルムから浮 き，剥がれがないようにする必要がある。一方，LCD メー カーの工程では, 表面保護フィルムが剥がし易く, 糊残り がないようにする必要がある。

これらの工程毎の要求性能に対して, 図 4 に要求される

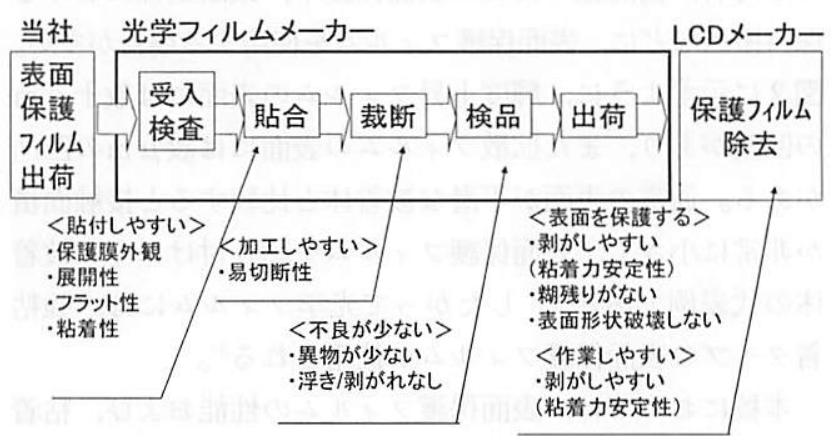

図 3 表面保護フィルムの各工程における要求性能

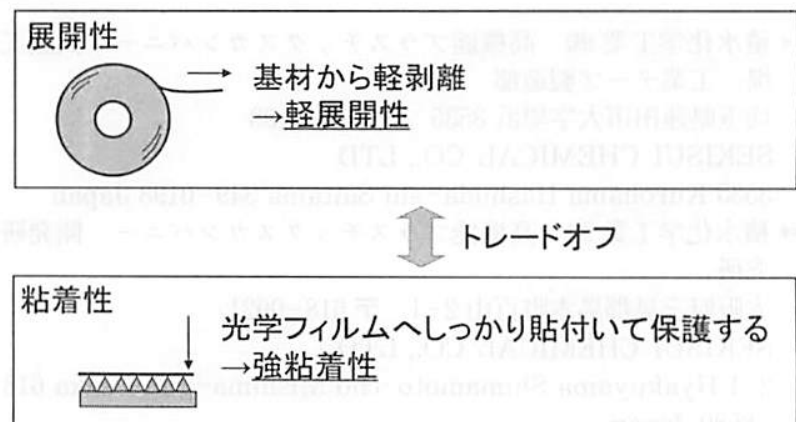

図 4 要求される代表的な性能 
代表的な性能を示す。展開力とは, 表面保護フィルムをロー ルから繰り出す時の力を意味する。重い展開力では, 表面 保護フィルムを強い力でロールから繰り出さなければなら ず，そのために表面保護フィルムが引き延ばされてしまう ことや, 表面保護フィルム中に残留応力が残り, 光学フィ ルムに表面保護フィルムを貼り付けた後, 浮き・剥がれが 起こる恐れがある。このような理由から基材からの軽展開 性が必要となる。一方, 粘着性では光学フィルムへしっか り貼り付いて表面を保護することや, 光学フィルムからの 表面保護フィルムの浮き・剥がれが起こらないように強い 粘着力が必要である。したがって, 軽展開性と強粘着性は トレードオフの関係になる。

本稿では, この二つの相反する性能のうち, 軽展開性の 樹脂設計に焦点を絞って紹介する。

\section{3. 表面保護フィルムの性能}

\section{1 製造方法}

図 5 に示すように表面保護フィルムを大別すると基材層 と粘着層から構成される。図 6 に表面保護フィルムの溶剂 染工法及び，共押出製法の製造方法を示す。一般的に溶剤

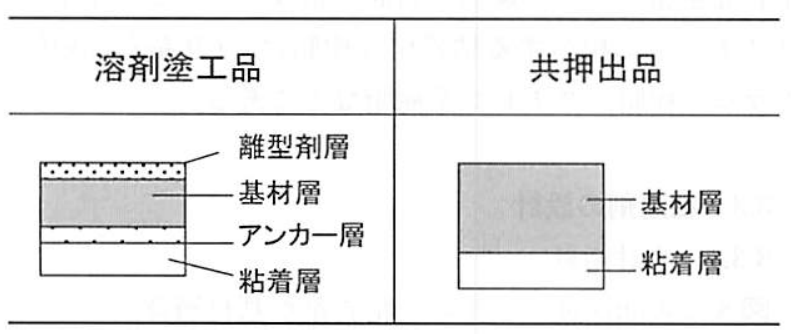

図 5 表面保護フィルムの構成

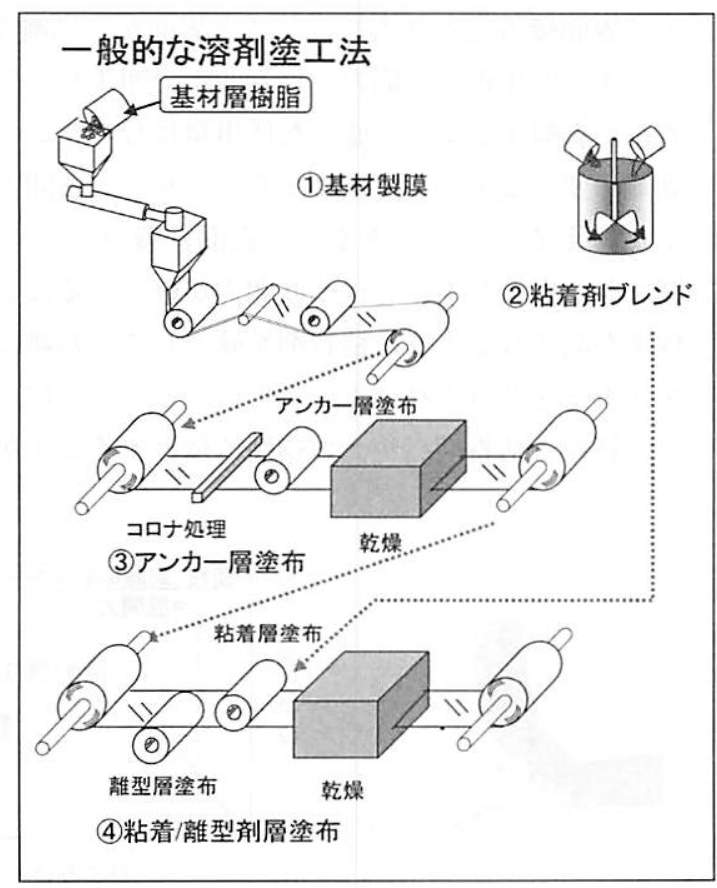

塗工法は, 予め基材を製膜した後に, 粘着剂を溶剂塗工・ 乾燥することで製造している。この方法は，溶剤による粘 度調節によって塗工することができるため, 粘着阂厚みの 制御に優れているなどの利点がある4)。さらに展開力を容 易にするために基材背面に離型剤層, 粘着剂と基材の接着 性を高めるために基材と粘着層の間にアンカー層を形成て きる5)。一方, 共押出製法で製造した表面保護フィルムは, 基材と粘着阂を溶融状態で多層化して製造している。その ため, 溶剤塗工法よりあ基材と粘着剤が強固に密着し, 表面保護フィルムを除去する時に糊残りが起こらない。さ らに，溶剤を使用しないだけでなく基材層と粘着層を同時 に製膜できるため，環境に易しい上，低コスト化が可能て ある。これらの特徴から，共押出製法が近年注目されてい $ろ^{6)}$ 。

しかし，共押出製法で製造した表面保護フィルムの基材 背面には, 溶剤塗工法のように離型剂層を形成することが 困難なため, 展開力が溶剤塗工法で製造した表面保護フィ ルムよりむ重くなるという課題がある。

\section{2 粘着剤の構成}

\section{2 .1 熱可塑性エラストマー}

光学フィルムに使う強粘着表面保護フィルムの粘着層は, 熱可塑性エラストマーをベース樹脂として用いている。

図 7 は，代表的なスチレン系ブロックポリマーであるス チレンーブタジェンースチレンブロック共重合体 (SBS)

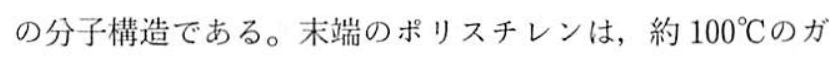
ラス転移温度 $(\mathrm{Tg})$ を持つ熱可塑性プラスチックスである のに対し, 中間ブロックには室温よりかなり低い約 $-95^{\circ} \mathrm{C}$

図 6 表面保護フィルムの製造方法

\section{共押出製法}

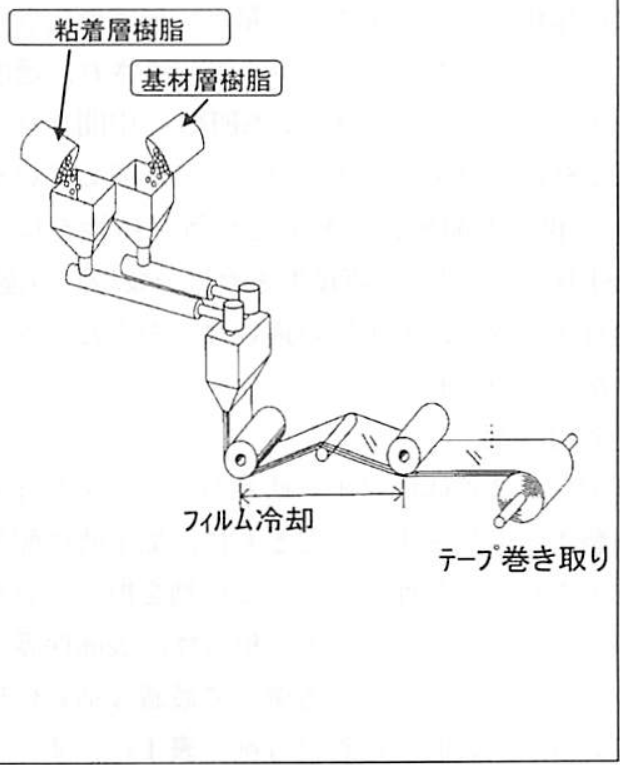




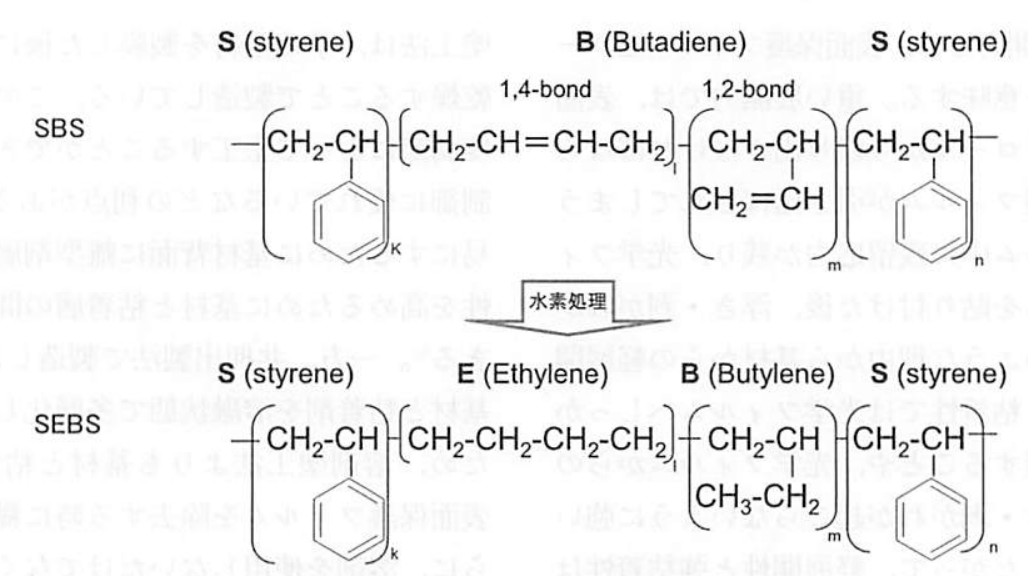

図 7 SBS および, SEBS の分子構造

表 1 粘着付与剤の種類

\begin{tabular}{|c|c|c|}
\hline \multirow[t]{2}{*}{ 天然樹脂系 } & ロジン系 & ロジン、ロジン誘導体 (水素化、不均化、重合、エステル化) \\
\hline & テルペン系 & $\begin{array}{l}\text { テルペン樹脂 }(\alpha 、 \beta-\text { ピネン)、テルペンフェノール樹脂、 } \\
\text { 芳香族変性テルペン樹脂、水素化テルペン樹脂 }\end{array}$ \\
\hline \multirow[t]{2}{*}{ 合成樹脂系 } & 石油樹脂系 & 脂肪族系、芳香族系、共重合系、水添系（脂環系） \\
\hline & その他 & $\begin{array}{l}\text { アルキルフェノール樹脂、キシレン樹脂、 } \\
\text { クマロンインデン樹脂 }\end{array}$ \\
\hline
\end{tabular}

の $\mathrm{Tg}$ を持つポリブタジェンを用いている。この 2 種類の ブロックは, 熱力学的に相溶しないため，ポリスチレンの 末端ブロックは, 互いに凝集してドメインを形成し，均一 に分散している7.8.9)。

しかしながらSBSは, 中間ブロックにポリブタジェン の共役二重結合を含むため, 熱, 紫外線に弱いという欠点 を持っている。そこで中間ブロックを水素添加処理したス チレンー（エチレン・ブチレン）ースチレンブロック共重 合体（SEBS）がある。ポリ（エチレン・ブチレン）は, 共役二重結合を有するポリブタジェンの 1,4 結合および 1,2 結合の水素添加処理によって得られたポリエチレンおよび ポリブチレンのランダム共重合体である。この中間ブロッ クは，主に結晶化するポリエチレン量と，無定形化させる ためのポリブチレン量が適切にコントロールされ，適度な ゴム弾性を生みだしている。また, SEBS の中間ブロック は，共役二重結合を含まないオレフィンで形成しているた め, SBS より優れた耐候性, 熱安定性等の特性を持って いる10,11)。SEBS は，構造（直鎖型または分岐型）の違い， スチレン含有量の違い, 分子量の荤いなどからたくさんの 品種が各社から上市されている。

\section{2 .2 粘着付与郕}

粘着付与剤は, 被着体に対する粘着力とタックを与え, 粘弾性を調整する役割を果たすとともに，加工時に配合物 の粘度を低下させ，作業性を良くする役割を担っている。 使用する熱可塑性エラストマーとの相溶性, 表面保護つィ ルムに求められる性能・品質を考慮して最適な粘着付与剂 を選定している。代表的な粘着付与剤を表 1 に示す ${ }^{12,13)}$ 。 SEBS のポリ（エチレン・ブチレン）に相溶する粘着付与
剤は, ロジン系, テルペン樹脂, 水添テルペン樹脂, C5 系石油樹脂, 水添脂環族系石油樹脂などである。末端のポ リスチレンに相溶する粘着付与樹脂は, C9 系石油樹脂, クマロン樹脂，スチレン系樹脂などである。

\section{3 粘着剤の設計}

\subsection{1 設計指針}

図 8 に表面保護フィルムの粘着剤が基材層背面から引き 剥がれる様子および, 粘着剤の応力一歪み曲線にしたがっ て応力が発生する様子を示す。粘着剤は, その応力が基材 との界面接着力より大きくなると界面から剥離する。図 8 に示す界面接着力と応力ー歪み曲線で囲まれた面積は, 粘 着剂が剥離するまでに要した仕事量になる。この仕事量が 剥離に要するエネルギーになることから，展開力に相当す ると考えることができる ${ }^{14)}$ 。表面保護フィルムの場合, 囲まれた面積が小さいほど展開力が軽くなることから, 弾 性率が高くなるように粘着剤を硬くして，剥離に要するエ ネルギーを低滅すればよいことになる。さらに，粘着テー プの特性は粘着剂バルクの物性に依存することから，剥離
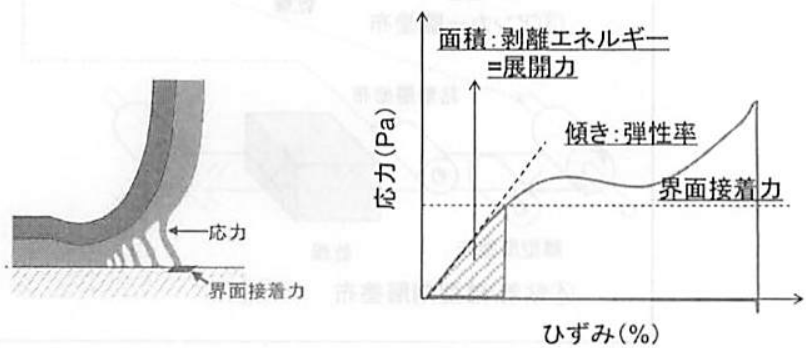

図 8 剥離断面図と粘着剤の応力一丕み曲線 




図 9 新規 SEBS の分子構造イメージ

と速度依存性が研究されている ${ }^{16)}$ 。表面保護フィルムの繰 り出し速度へも同様な研究理論が適用できることから, 時 間一温度換算則より，動的粘弾性挙動の高周波数の振動 (高速剥離速度) は周期が短いので低温領域と, 低周波数 の振動（低速剥離速度）は周波数が長いので高温領域と等 価であると考えられる ${ }^{15)}$ 。表面保護フィルムを数十 $\mathrm{m} /$ 分 の速度で繰り出すと想定すると, その速度は低温領域に相 当する ${ }^{16,17)}$ 。

以上のことから，われわれは応力ー歪み曲線および動的 粘弾性から, 低温領域の弾性率を高くして展開力低隇を狙っ た。但し，粘着性に影響する室温付近の弾性率は維持する 熱可塑性エラストマーの設計とする。

\subsection{2 構造制御}

図 9 に示すように一般的な SEBS は, A-B-A 型のブ ロック共重合体である。しかし，われわれは検討した結果， SEBS の一次構造を制御することに至り, 試作(1), (2)のよ うに中間ブロックのポリ（エチレン・ブチレン）にポリス チレンを共重合した。試作(2)は, 試作(1)の中間ブロックに そのポリスチレンの 1.5 倍量を共重合している。図 10 に SEBS の動的粘弾性挙動を示すように, 中間ブロックのポ リ（エチレン・ブチレン）にポリスチレンを共重合した試 作(1)は, 現行の SEBS と比べ, 約 $-50^{\circ} \mathrm{C}$ 付近に見られたポ リ（エチレン・ブチレン）の $\mathrm{Tg}$ が約 $-40^{\circ} \mathrm{C}$ ま゙シフトし ている。さらに試作(2)は, 中間ブロックにポリスチレンを 増量しているため, $\mathrm{Tg}$ が約 $-20^{\circ} \mathrm{C}$ までシフトしている。 $\mathrm{Tg}$ がシフトしたメカニズムは, 中間ブロックに硬いポリ スチレンを共重合したためポリ（エチレン・ブチレン）の 運動性を拘束したためである。 Tg が高温にシフトしたこ とから, 繰り出し速度に相当する低温領域の弾性率が高く なった。ポリスチレン量が増すとゴム状平坦領域の弾性率 も高くなると予想されるが, 現行の SEBS と同等な弾性 率挙動を示している。これは, 中間ブロックに共重合した ポリスチレン量が極僅かな重合度であることと, ポリ（エ チレン・ブチレン) の流動域の運動に影響を受けるので, ゴム状平坦領域の弾性率は現行の SEBS と同等である。

以上のことから, 展開力に影響する低温領域の弾性率お よび, 粘着性に影響する室温付近の弾性率を両立する分子

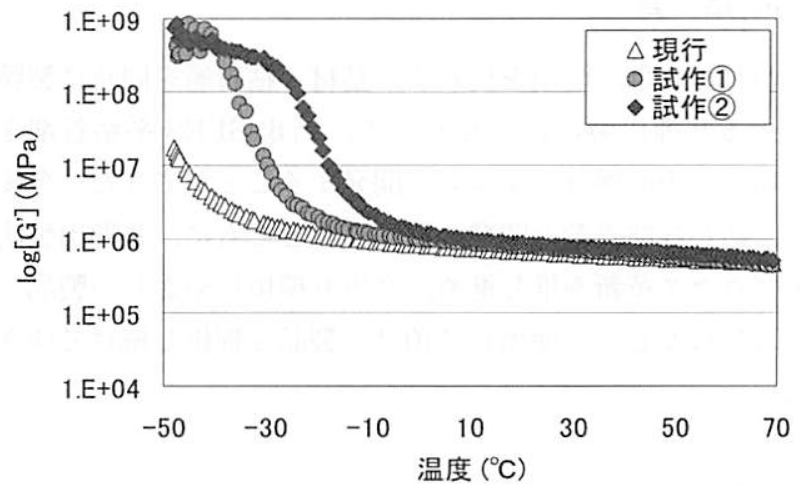

図 10 SEBS の温度依存性

の構造制御が可能になる。

\section{4. 新規 SEBS の性能}

中間ブロックのポリ（エチレン・ブチレン）にポリスチ レンを共重合した新規 SEBS を使い表面保護フィルムを 共押出製法で製膜した。図 11 に展開力と低温側の弾性率 の関係を示すように, 試作(1), (2)の展開力は, 現行の SEBS より $1 / 2$ 以下に低下した。さらに 3.3 で述べたとお り, 展開力は低温側の弾性率に依存して低温側の弾性率が 高いほど，展開力が下がることを確認した。

われわれは, 中間ブロックのポリ（エチレン・ブチレン） にポリスチレンを共重合した新規 SEBS を使い表 2 に示 すように 6800 シリーズの表面保護フィルムを上市してい る。

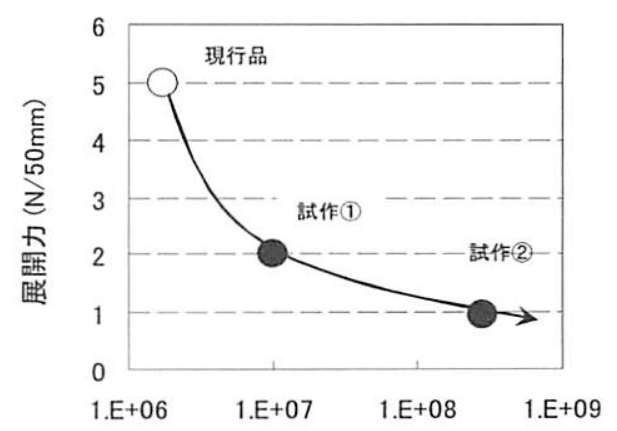

低温側の弾性率 $(\mathrm{Pa})$

図 11 弾性率と展開力の関係 
表 2 当社の強粘着夕イプ表面保護フィルム

\begin{tabular}{|c|c|c|c|c|c|}
\hline \multicolumn{2}{|c|}{ 品名 } & $6842 B$ & $6845 B$ & $6847 \mathrm{~B}$ & \multirow[t]{2}{*}{ 試験方法 } \\
\hline \multicolumn{2}{|c|}{ 色 } & \multicolumn{3}{|c|}{ 透明 } & \\
\hline 標準厚み & $\mu \mathrm{m}$ & \multicolumn{3}{|c|}{40} & 呼称値 \\
\hline \multicolumn{2}{|c|}{$\begin{array}{l}\text { 粘着力 } \mathrm{N} / 25 \mathrm{~mm} \\
\left(23^{\circ} \mathrm{C} 、 \mathrm{PMMA} \text { 板 }\right)\end{array}$} & 0.6 & 1.0 & 1.5 & $\begin{array}{c}\text { 剥離速度 } \\
300 \mathrm{~mm} / \mathrm{min} \\
\text { 剥離角度 } 90^{\circ}\end{array}$ \\
\hline \multicolumn{2}{|c|}{ クリーンルーム生産 } & $\mathrm{O}$ & O & O & - \\
\hline
\end{tabular}

\section{5. 結 言}

われわれは，溶剤を使わず，基材・粘着層を同時に製膜 できる共押出製法にこだわって，新規 SEBS 系粘着剤を 活用した表面保護フィルムを開発することができた。今後 も，新たな粘着剤の開発に取り組むとともに，共押出製法 のプロセス革新を推し進め, 今後も環境にやさしい製品, お客様に安心して使用して頂ける製品を提供し続けてゆき たい。

\section{謝辞}

本製品を開発するにあたり,諸先輩方を始めとして, 開 発, 製造, 生産管理, 品質保証, 知財, 営業に関わる多く の関係者の方々，また，製品を採用して頂くにあたりご評 価頂きましたお客様より多くのご助言，ご協力を頂きまし た。ここに深く感謝の意を表します。
参考 文 献

1）前田紀一，“輝度上昇フィルムの複合化”，FPD International セミナー, E-3 (2003).

2）月刊ディスプレイ，3月，27 (2008).

3）日立化成テクニカルレポート，41,23 (2003).

4） 日本粘着テープ工業会, “粘着ハンドブック第 2”, 189 (1995).

5） 日立化成テクニカルレポート，38,7（2002）。

6) 村上健吉, “押出成形第 7 版”, 244 (1985).

7） コンパーテック 11,46 (2000).

8）コンパーテック 5, 70 (2009).

9）日本ゴム協会誌，9,57 (2002).

10）コンパーテック 3,64 (2003).

11）日本接着学会誌，42, 425 (2006).

12）日本粘着テープ工業会“粘着ハンドブック第 3 版”, 49 (2005).

13）岡崎巧，接着の技術，20, 2, 13 (2000).

14）技術情報協会“粘着剤・テープ設計のためのバルク・界面 の解析と特性評価”22(2008).

15）情報機構“粘着・剥離のメカニズムと各種用途における性 能コントロール”27 (2009).

16）日本ゴム協会誌，77，186（2004）。

17）日本ゴム協会誌，77, 250 (2004). 